\title{
PENGARUH KEPUASAN KERJA TERHADAP TURNOVER INTENTION DENGAN KOMITMEN ORGANISASI SEBAGAI VARIABEL INTERVENING
}

\author{
Azisah Putri Ayu Ningtyas ${ }^{1}$ \\ Suseno Hadi Purnomo \\ Aswar $^{3}$ \\ Stiem Bongaya, Makassar, Indonesia \\ email Azizahputriayuningtyas@gmail.com \\ , susenohadipurnomo73069@gmail.com, aswar.phobia@gmail.com
}

\begin{abstract}
ABSTRAK
Penelitian ini bertujuan untuk menganalisis Pengaruh kepuasan kerja terhadap turnover intention dengan komitmen organisasi sebagai variabel intervening.Pendekatan penelitian ini adalah kuantitatif. Populasi dalam penelitian ini adalah karyawan tetap yang berada di PT. Astra International Tbk, Honda. Sampel penelitian ini sebanyak 100karyawan dalam PT. Astra International Tbk, Honda dengan menggunakan analisis jalur. Dari model analisis tersebut nilai dari variabel dependen diperoleh dari hasil kuesioner dan menggunakan skala likert. Hasil penelitian ini menunjukkan bahwa model yang diteliti telah memenuhi uji kelayakan model. Kepuasan kerja yang menunjukkan hasil positif dan signifikan terhadap komitmen organisasi, kepuasan kerja menunjukkan hasil positif dan signifikan terhadap turnover intention, komitmen organisasi menunjukkan hasil positif dan signifikan terhadap turnover intention dankepuasan kerjaberpengaruh positif signifikan terhadap turnover intention melalui komitmen organisasi.
\end{abstract}

Kata Kunci : kepuasan kerja, turnover intention, komitmen organisasi.

\begin{abstract}
This study aims to analyze the effect of job satisfaction on turnover intention with organizational commitment as an intervening variable. The approach of this study is quantitative. The population in this study are permanent employees who are in PT. Astra International Tbk, Honda. The sample of this study were 100 employees in PT. Astra International Tbk, Honda using path analysis. From the analysis model the value of the dependent variable was obtained from the results of the questionnaire and using a Likert scale. The results of this study indicate that the model studied has met the model's feasibility test. Job satisfaction shows positive and significant results on organizational commitment, job satisfaction shows positive and significant results on turnover intention, organizational commitment shows positive and significant results on turnover intention and job satisfaction has a significant positive effect on turnover intention through organizational commitment.

Keywords: Job satisfaction, turnover intention, organizational commitments.
\end{abstract}




\section{PENDAHULUAN}

Keberhasilan dan kesuksesan suatu perusahaan sangat ditentukan dari bagaimana perusahaan mengelola sumber daya yang dimilikinya, hal tersebutlah yang membuat para pengusaha sadar akan nilai investasi karyawan sebagai salah satu aset penting perusahaan. Sumber daya merupakan kemampuan untuk berbuat sesuatu, dan memanfaatkan kesempatan yang ada, dan kemampuan untuk bisa membebaskan diri dari kesulitan yang dialami (Ardana dkk.,2012). Sumber daya manusia adalah kemampuan terpadu dari daya pikir dan daya fisik yang dimiliki individu, perilaku dan sifatnya ditentukan oleh keturunan dan lingkungannya, sedangkan prestasi kerjanya dimotivasi oleh keinginan untuk memenuhi kepuasannya (Hasibuan, 2013).

Teori kepuasan kerja yang dikemukakan Hersberg (2000) dalam Sinollah (2011) menyatakan bahwa terdapat dua faktor penentu kepuasan kerja, yaitu; pertama, kebutuhan akan kesehatan atau kebutuhan akan pemeliharaan. Hal ini berhubungan dengan hakikat manusia yang ingin memperoleh ketentraman lahiriyah. Faktor-faktor pemeliharaan meliputi balas jasa, kondisi kerja fisik, kepastian pekerjaan, supervise yang menyenangkan, mobil dinas, rumah dinas, dan bermacam-macam tunjangan lainnya. Hilangnya faktor pemeliharaan ini dapat menyebabkan timbulnya ketidakpuasan dan tingkat absensi karyawan serta turnover akan meningkat. Faktor-faktor pemeliharaan ini perlu mendapat perhatian yang wajar dari pimpinan agar kepuasan dan kegairahan kerja karyawan dapat ditingkatkan. Kedua, faktor pemeliharaan ini menyangkut kebutuhan psikologi seseorang. Kebutuhan ini meliputi serangkaian kondisi instrinsik, kepuasan pekerjaan yang apabila terdapat dalam pekerjaan akan menggerakkan tingkat motivasi yang kuat yang dapat menghasilkan prestasi kerja yang baik. Jika kondisi ini tidak ada maka kondisi ini ternyata menimbulkan rasa ketidakpuasan yang berlebihan. Serangkaian faktor ini dinamakan satisfier atau motivators yang meliputi: Prestasi, Pengakuan, Pekerjaan itu sendiri, Tanggung jawab, Kemajuan dan Pengembangan potensi individu.

Berdasarkan teori tersebut maka dapat dijelaskan bahwa salah satu faktor yang terjadi ketika karyawan tidak merasa puas terhadap pekerjaan yang ia lakukan maka dapat terjadi trunover.Turnover dapat diartikan sebagai pergerakan tenaga kerja keluar dari organisasi. Turnover mengarah pada kenyataan akhir yang dihadapi suatu organisasi berupa jumlah karyawan yang meninggalkan organisasi pada periode tertentu keinginan karyawan untuk berpindah (turnover intention) mengacu pada hasil evaluasi individu mengenai kelanjutan hubungan dengan organisasi yang belum diwujudkan dalam tindakan pasti meninggalkan organisasi (witasari, 2009). Turnover dapat berupa pengunduran diri, perpindahan keluar unit organisasi, pemberhentian atau kematian anggota organisasi. Turnover adalah pengukuruan apakah karyawan suatu perusahaan atau organisasi berenvana untuk meninggalkan posisinya atau organisasi berencana untuk menghilangkan karyawan dari posisinya. Intense turnover dapat bersifat sukarela atau tidak sukarela (saklit, 2017). Lebih lanjut (Staffelbach ,2008) menguraikan turnover intention merupakan kemungkinan yang bersifat subyektif dimana seorang individu akan merubah pekerjaannya dalam jangka waktu tertentu dan merupakan pelopor dasar kepada turnover yang sebenarnya. Fakta lapangan menunjukkan 
bahwa Stres kerja, beban kerja,lingkungan kerja dan komitmen organisasi merupakan variabel penting yang berpengaruh dengan turnover intention karyawan sehingga menyebabkan rendahnya tingkat kepuasan karyawan terhadap perkerjaan yang dilakukannya.

Semakin rendah tingkat kepuasan kerja karyawan maka semakin tinggi tingkat turnover intention karyawan. Pernyataan tersebut merujuk pada hasil penelitian terdahulu yang dilakukan oleh (Dewi, 2019) bahwa kepuasan kerja karyawan berpengaruh negatif dan signifikan terhadap trunover.Pernyatan tersebut juga didukung oleh hasil penelitian penelitian (Setiyanto \& Hidayati, 2017) bahwa kepuasan kerja berpengaruh negatif dan tidak signifikan terhadap turnover intention Karyawan.

Salah satu elemen penting yang dapat mempengaruhi trunover intention karyawan adalah komitmen organisasi. Masalah komitmen organisasi menjadi suatu hal yang sangat penting karena akan berdampak pada prestasi kerja karyawan dalam melaksanakan tugas dan tanggung jawabnya. Komiten organisasi didefinisikan sebagai suatu keadaan dimana seorang karyawan memihak organisasi tertentu serta tujuan tujuan dan keinginannya untuk mempertahankan keanggotaan dalam organisasi tersebut (Robbins \& Judge). Jadi, keterlibatan pekerjaan yang tinggi berarti memihak pada pekerjaan tertentu seorang individu, sementara komitmen organisasional yang tinggi berarti memihak organisasi yang merekrut individu tersebut. Dari beberapa definisi sebelumnya, dapat disimpulkan bahwa komitmen organisasi merupakan suatu hal yang lebih dari sekedar kesetiaan yang pasif melainkan menyiratkan hubungan pegawai dengan perusahaan secara efektif. Karyawan yang menunjukkan komitmen tinggi memiliki keinginan untuk memberikan tenaga dan tanggung jawab yang lebih dalam menyokong kesejahteraan dan keberhasilan organisasinya.

Fakta lapangan yang diperoleh pada saat dilakukan pra penelitian memberikan bukti bahwa komitmen organisasi yang dimliki oleh perusahaan cenderung tinggi, hal ini dapat dilihat dari komitmen yang diberikan perusahaan sudah baik bagi para karyawan.

Lebih lanjut (Mitchell,2004) menyatakan bahwa Komitmen organisasi merupakan loyalitas dan identifikasi individu terhadap organisasi. Mereka mempunyai komitmen tinggi cenderung lebih bertahan dan rendah absensinya dari pada yang komitmennya rendah. Jadi secara keseluruhan komitmen organisasi merupakan suatu keadaan sejauh mana seorang pegawai memihak pada suatu organisasi tertentu dan tujuannya, dan berminat memelihara ke anggotaan dalam organisasi tersebut untuk menjaga kelangsungan organisasi tersebut.

Manajemen sumber daya manusia didefinisikan sebagai suatu strategi dalam menerapkan fungsi-fungsi manajemen yaitu planning, organizing, leading and controlling, dalam setiap aktifitas atau fungsi operasional sumber daya manusia mulai dari proses penarikan, seleksi, pelatihan dan pengembangan, penempatan yang meliputi promosi, demosi dan transfer, penilaian kinerja, pemberian kompensasi, hubungan industrial, hingga pemutusan hubungan kerja, yang ditujukan bagi peningkatan kontribusi produktif dari sumberdaya manusia organisasi terhadap pencapaian tujuan organisasi secara lebih efektif dan efisien (Herman Sofyandi, 2009). 
Pandangan lainnya mendefinisikan bahwa manajemen sumber daya manusia adalah ilmu yang mempelajari bagaimana memberdayakan karyawan dalam perusahaan, membuat pekerjaan, kelompok kerja, mengembangkan para karyawan yang mempunyai kemampuan, mengidentifikasi suatu pendekatan untuk dapat mengembangkan kinerja karyawan dan memberikan imbalan kepada mereka atas usahanya dan bekerja (Bohlarander dan Snell, 2010).

Berdasarkan kedua definisi tersebut, maka manajemen sumber daya manusia dapat disimpulkan sebagai suatu strategi yang dipakai dalam sebuah organisasi dalam menerapkan fungsi-fungsi manajemen seperti, perencanaan, peorganisasian dan fungsi manajemen lainnya yang ditujukan untuk meningkatkan kontribusi sumber daya manusia dalam organisasi untuk mencapai tujuan. Manejemen sumber daya manusia memiliki peranan penting dalam pengelolaan instansi. Fungsi Manajemen Sumber Daya Manusia, meliputi:

Perencanaan adalah usaha sadar dalam pengambilan keputusan yang telah diperhitungkan secara matang tentang hal-hal yang akan dikerjakan di masa depan oleh suatu organisasi untuk mencapai tujuan yang telah dirancang sebelumnya. Rekrutmen, proses penarikan sekelompok kandidat untuk mengisi posisi yang lowong. Seleksi, seleksi tenaga kerja adalah suatu proses menemukan tenaga kerja yang tepat dari sekian banyak kandidat atau calon yang ada. Orientasi, pelatihan dan pengembangan, pelatihan merupakan proses pembelajaran yang melibatkan perolehan keahlian, konsep, peraturan, atau sikap untuk meningkatkan kinerja tenaga kerja. Evaluasi kinerja, evaluasi sama pentingnya dengan fungsi-fungsi manajemen lainnya, yaitu perencanaan, pengorganisasian atau pelaksanaan pemantauan (monitoring) dan pengendalian.

Kompensasi, pemberian balas jasa langsung dan tidak langsung berbentuk uang atau barang kepada pegawai sebagai imbal jasa (reward) yang diberikannya kepada perusahaan. Pengintegrasian, kegiatan untuk mempersatukan kepentingan perusahaan dan kebutuhan pegawai, sehingga tercipta kerjasama yang serasi dan saling menguntungkan. Pemeliharaan, kegiatan untuk memelihara atau meningkatkan kondisi fisik, mental dan loyalitas pegawai agar tercipta kerjasama yang panjang. Pemberhentian, pemutusan hubungan kerja adalah pengakhiran hubungan kerja karena suatu hal tertentu yang mengakibatkan berakhirnya hak dan kewajiban antar pekerja dan pengusaha.

Kepuasan kerja adalah suatu sikap umum terhadap pekerjaan seseorang sebagai perbedaan antara banyaknya ganjaran yang diterima pekerja dengan banyaknya ganjaran yang diyakini seharusnya diterima menurut Robbins (2015). Kepuasan kerja merupakan hal penting yang dimiliki individu di dalam bekerja. Setiap individu pekerja memiliki karakteristik yang berbeda - beda, maka tingkat kepuasan kerjanya pun berbeda - beda pula tinggi rendahya kepuasan kerja tersebut dapat memberikan dampak yang tidak sama. Menurut (Robbins, 2015), ukuran kepuasan sangat didasarkan atas kenyataan yang dihadapi dan diterima sebagai kompensasi usaha dan tenaga yang diberikan. Kepuasan kerja tergantung kesesuaian atau keseimbangan antara yang diharapkan dengan kenyataan. Menurut Robbins (2002), kepuasan kerja karyawan dipengaruhi oleh banyak faktor, antara lain : pekerjaan yang menantang, penghargaan, kondisi lingkungan kerja dan hubungan interpersonal. 
Kerja yang menantang secara mental. Pada umumnya individu lebih menyukai pekerjaan yang memberi peluang untuk menggunakan keterampilan dan kemampuan serta memberi beragam tugas, kebebasan dan feedback tentang seberapa baik pekerjaanya. Hal ini akan membuat pekerjaan lebih menantang secara mental. Pekerjaan yang kurang menantang akan menciptakan kebosanan, akan tetapi yang terlalu menantang juga dapat menciptakan frustasi dan perasaan gagal. Penghargaan yang sesuai. Karyawan menginginkan sistem bayaran yang adil, tidak ambigu, dan selaras dengan harapan karyawan. Saat bayaram dianggap adil, dalam arti sesuai dengan tuntutan pekerjaan, tingkat keterampilan individual, dan standar bayaran masyarakat, kemungkinan akan tercipta kepuasan. Kondisi kerja yang mendukung. Karyawan berhubungan dengan lingkungan kerjanya untuk kenyamanan pribadi dan kemudahan melakukan pekerjaan yang baik. Yang termasuk didalamnya seperti tata ruang, kebersihan ruang kerja, fasilitas dan alat bantu, temperatur, dan tingkat kebisingan. Kolega yang suportif. Individu mendapatkan sesuatu yang lebih daripada uang atau prestasi yang nyata dari pekerjaan tetapi karyawan juga memenuhi kebutuhan interaksi sosial. Perilaku atasan juga merupakan faktor penentu kepuasan yang utama. Oleh karena itu, perlu diterapkan rasa saling menghargai, loyal dan toleran antara satu dengan yang lain, sikap terbuka, dan keakraban antar karyawan.

Pergantian karyawan atau keluar masuknya karyawan dari organisasi adalah suatu fenomena penting dalam kehidupan organisasi. Ada kalanya pergantian karyawan memiliki dampak positif. Namun sebagian besar pergantian karyawan membawa pengaruh yang kurang baik terhadap organisasi, baik dari segi biaya maupun dari segi hilangnya waktu dan kesempatan untuk memanfaatkan peluang dalam arti luas, "turnover diartikan sebagai aliran para karyawan yang masuk dan keluar perusahaan" (Ronodipuro dan Husnan, 1995). Sedangkan (Mobley,1986), megemukakan bahwa batasan umum tentang pergantian karyawan adalah : "berhentinya individu sebagai anggota suatu organisasi dengan disertai pemberian imbalan keuangan oleh organisasi yang bersangkutan".

Secara umum karyawan yang keluar dari perusahaan biasanya disebabkan oleh 2 (dua) hal (Kasmir, 2016:321), yaitu: Diberhentikan maksudnya adalah karyawan diberhentikan dari perusahaan disebabkan oleh berbagai sebab, misalnya telah memasuki usia pensiun, atau mengalami cacat sewaktu bekerja, sehingga tidak mampu lagi bekrja. Untuk yang pensiun alasannya karena sudah memasuki usia pensiun, sedangkan yang dipensiunkan karena cacat, karena dianggap sudah tidak atau kurang memiliki kemampuan, sehingga tidak mampu lagi bekerja seperti semula. Kemudian diberhentikan juga dapat dilakukan perusahaan karena karyawan. Melakukan perbuatan yang telah merugikan perusahaan, misalnya kasus penipuan,pencurian atau hal-hal yang merugikan lainnya. Artinya karyawan berhenti dengan keinginan atau permohonannya sendiri, untuk keluar dari perusahan, tanpa campur tangan pihak perusahaan. Alasan pemberhentian ini juga bermacam-macam, misalnya karena masalah lingkungan kerja yang kurang kondusif, kompensasi yang kurang, atau jenjang karir yang tidak jelas atau ketidaknyamanan lainnya. Alasan seperti ini terkadang tidak dapat diproses oleh pihak sumber daya manusia dan berusaha untuk dipertahankan dengan pertimbangan berbagai hal, misalnya kemampuan 
karyawan masih dibutuhkan. Namun jika karyawan tersebut merasa tidak diperlukan tenaganya, maka segera akan diproses untuk diberhentikan, karena jika karyawan yang sudah minta berhenti dan tetap dipertahankan, akan mengakibatkan motivasi kerjanya lemah dan berdampak kepada kinerjanya. Bahkan banyak kasus terkadang karyawan tersebut membuat ulah yang dapat mengganggu operasi perusahaan.

Komitmen organisasi adalah ikatan keterkaitan individu dengan organisasi, sehingga individu tersebut "merasa memiliki" organisasinya. Komitmen menunjukkan keyakinan dan dukungan yang kuat terhadap nilai dan sasaran yang ingin dicapai oleh organisasi. Komitmen organisasi yang tinggi dapat diperlukan dalam sebuah organisasi, karena terciptanya komitmen yang tinggi akan mempengaruhi situasi kerja yang professional. Komitmen organisasi bisa tumbuh disebabkan karena individu memiliki ikatan emosional terhadap organisasi yang meliputi dukungan moral dan menerima nilai yang ada serta tekad dari dalam diri individu untuk berbuat sesuatu agar dapat menunjang keberhasilan organisasi sesuai dengan tujuan dan lebih mengutamakan kepentingan organisasi dibandingkan dirinya sendiri. ( Mowday, 1982) menyebut komitmen kerja sebagai istilah lain dari komitmen organisasional. Menurut dia, komitmen organisasional merupakan dimensi perilaku penting yang dapat digunakan untuk menilai kecenderungan karyawan untuk bertahan sebagai anggota organisasi. Komitmen organisasional merupakan identifikasi dari keterlibatan seseorang yang relatif kuat terhadap organisasi. Komitmen organisasional adalah keinginan anggota organisasi untuk tetap mempertahankan keanggotaannya dalam organisasi dan bersedia berusaha keras bagi pencapaian tujuan organisasi. Sedangkan menurut (Supriono, 2004) berpendapat bahwa sesorang dapat merasa terikat dan komitmen dengan lingkup organisasi dikarenakan faktor pekerjaan, jabatan dan keberadaannya. Hubungan korelasi antara komitmen organisasi dan pekerjaan lain yang terkait. Korelasi tersebut digambarkan terkait dengan keseluruhan kepuasan kerja, kinerja, berhenti dalam bekerja, dengan kepribadian seorang pegawai. Komitmen organisasional mencakup kebanggaan anggota, kesetiaan anggota, dan kemauan anggota pada organisasi. Menurut Juniarari (2011) mengemukakan bahwa manfaat dari komitmen organisasi yaitu diantaranya :

Karyawaan yang serius dalam menunjukkan komitmen tinggi kepada organisasi memiliki kemungkinan yang jauh lebih tinggi untuk menunjukkan tingkat keikutsertaan yang tinggi dalam sebuah organisasi. Memiliki kemauan yang kuat untuk tetap bekerja di organisasi yang sekarang dan selalu memberikan sumbangan untuk mencapai tujuan. Dengan kesungguhan terlibat dengan pekerjaan, karena pekerjaan tersebut ialah mekanisme kunci \& saluran individu untuk memberikan sumbangan untuk tercapainya tujuan organisasi.

Berdasarkan hasil penelitian sebelumnya, hipotesis yang dapat diajukan dalam penelitian ini adalah:

$\mathrm{H}_{1}$ : Kepuasan kerja berpengaruh terhadap komitmen organisasi.

Individu, sebagian besar, mencari pekerjaan yang cocok dengan karakternya sehingga dapat memenuhi preferensi mereka. Dalam perjalanannya, organisasi dan individu secara dinamis melakukan interaksi yang bisa saja menimbulkan ketidaksesuaian. Ketidaksesuaian ini ditangkap oleh individu dalam bentuk sikap. 
Dua sikap penting dalam organisasi yang memengaruhi atau sebagai anteseden kinerja, turnover, ketidakhadiran, dan wujud perilaku kontra produktif lainnya yaitu kepuasan kerja dan komitmen organisasi (Kell \& Motowidlo, 2012). Lebih lanjut, hal tersebut dilihat sebagai sikap stabil afeksi umum terhadap perusahaan dan umumnya dilihat lebih stabil dan global dari pada kepuasan kerja (Perryer et al., 2010). Sebagai hasil, (Meyer \& Maltin, 2010; Perryer et al., 2010) menyebutkan komitmen organisasi berasal dari kepuasan kerja, pengalaman kerja positif, kepercayaan dalam manajemen, serta renumerasi dan penghargaan yang menarik. Sejalan dengan teori di atas, penelitian terdahulu (Ismail \& Razak, 2016; Puspitawati \& Riana, 2014), dan (Hsiao et al., 2012) yang menyebut komitmen organisasi sebagai hasil dari kepuasan kerja memperlihatkan kepuasan kerja sebagai anteseden komitmen organisasi.

Menurut Robbins (2002), kepuasan kerja karyawan dipengaruhi oleh banyak faktor, antara lain : pekerjaan yang menantang, penghargaan, kondisi lingkungan kerja dan hubungan interpersonal. Kerja yang menantang secara mental. Pada umumnya individu lebih menyukai pekerjaan yang memberi peluang untuk menggunakan keterampilan dan kemampuan serta memberi beragam tugas, kebebasan dan feedback tentang seberapa baik pekerjaanya. Hal ini akan membuat pekerjaan lebih menantang secara mental. Pekerjaan yang kurang menantang akan menciptakan kebosanan, akan tetapi yang terlalu menantang juga dapat menciptakan frustasi dan perasaan gagal. Penghargaan yang sesuai. Karyawan menginginkan sistem bayaran yang adil, tidak ambigu, dan selaras dengan harapan karyawan. Saat bayaram dianggap adil, dalam arti sesuai dengan tuntutan pekerjaan, tingkat keterampilan individual, dan standar bayaran masyarakat, kemungkinan akan tercipta kepuasan.

Kondisi kerja yang mendukung. Karyawan berhubungan dengan lingkungan kerjanya untuk kenyamanan pribadi dan kemudahan melakukan pekerjaan yang baik. Yang termasuk didalamnya seperti tata ruang, kebersihan ruang kerja, fasilitas dan alat bantu, temperatur, dan tingkat kebisingan.Kolega yang suportif. Individu mendapatkan sesuatu yang lebih daripada uang atau prestasi yang nyata dari pekerjaan tetapi karyawan juga memenuhi kebutuhan interaksi sosial. Perilaku atasan juga merupakan faktor penentu kepuasan yang utama. Oleh karena itu, perlu diterapkan rasa saling menghargai, loyal dan toleran antara satu dengan yang lain, sikap terbuka, dan keakraban antar karyawan.

Berdasarkan hasil penelitian sebelumnya, hipotesis yang dapat diajukan dalam penelitian ini adalah:

$\mathrm{H}_{2}$ : Kepuasan kerja berpengaruh terhadap turnover intention.

Penelitian yang dilakukan oleh Salleh et al. (2012) menunjukan bahwa semua aspek kepuasan kerja yang meliputi promosi, pekerjaan itu sendiri, serta supervise kecuali rekan kerja berpengaruh negatif terhadap turnover intention. Pembuktian pengaruh negatif yang dilakukan peneliti berupaya untuk menjelaskan bahwa semakin tinggi kepuasan kerja, maka niat keluar karyawan dari perusahaan cenderung rendah (Rita Andini, 2006). Penelitian yang dilakukan oleh Kristanto (2014) menunjukan bahwa kepuasan kerja berpengaruh negatif dan signifikan terhadap turnover intention. Penelitian tersebut juga sejalan dengan penelitian yang dilakukan Saeed et al. (2014) yang menyatakan bahwa kepuasan 
kerja berpengaruh negatif terhadap turnover intention. Leisanyane dan Khaola (2013) dalam penelitiannya juga menemukan adanya kolerasi negatif dan signifikan anatara kepuasan kerja dan turnover intention.Adanya pengaruh kepuasan kerja terhadap turnover intention Agung dkk. (2013) dalam penelitiannya juga menemukan bahwa kepuasan kerja berpengaruh negatif dan signifikan terhadap turnover intention karyawan.

Berdasarkan hasil penelitian sebelumnya, hipotesis yang dapat diajukan dalam penelitian ini adalah:

$\mathrm{H}_{3}$ : Komitmen organisasi berpengaruh terhadap turnover intention.

Penting untuk melihat komitmen organisasi tidak hanya sebagai hasil akhir, melainkan menjadi anteseden yang mengarah pada hasil. Karyawan yang lebih memiliki komitmen organisasi diasosiasikan sebagai sikap cenderung lebih sedikit melakukan perilaku kontra produktif (Suifan et al., 2017). Hal yg membuat komitmen organisasi lebih menarik adalah kenyataan bahwa komitmen organisasi telah terbukti sangat mengurangi turnover intention (Kaur \& Mahajan, 2014). Hal itu dapat dimengerti karena tingkat komitmen yang rendah merangsang sikap penarikan diri seperti turnover intention. Terdapat hasil yang berbeda mengenai pengaruh komitmen organisasi terhadap turnover intention dalam penelitian terdahulu. Penelitian terdahulu yang dilakukan (Amri et al., 2017; Sutanto \& Gunawan, 2013) memperlihatkan turnover intention dipengaruhi secara negatif oleh komitmen organisasi.

Mobley (2011) menyatakan bahwa faktor-faktor yang mempengaruhi seseorang untuk berpindah ditentukan oleh Besar kecilnya organisasi, ada hubungannya dengan pergantian karyawan yang tidak bergitu banyak, karena organisasi-organisasi yang lebih besar mempunyai kesempatan-kesempatan mobilitas intern yang lebih banyak, seleksi personalia yang canggih dan prosesproses manajemen sumber daya manusia, sistem imbalan yang lebih bersaing, serta kegiatan-kegiatan penelitian yang dicurahkan bagi pergantian karyawan.

Besar kecilnya unit kerja, mungkin juga berkaitan dengan pergantian karyawan melalui variabel-variabel lain seperti keterpaduan kelompok, personalisasi, dan komunikasi. Ada tanda-tanda yang menunjukan bahwa unit-unit kerja yang lebih kecil, terutama pada tingkat tenaga kerja kasar, mempunyai tingkat pergantian karyawan yang lebih rendah. Penggajian, para peneliti telah memastikan bahwa ada hubungan yang kuat antara tingkat pembayaran dan laju pergantian karyawan. Selain itu faktor penting yang menentukan variasi-variasi antar industri dalam hal pelepasan sukarela adalah tingkat penghasilan yang relatif. Pergantian karyawan ada pada tingkat tertinggi dalam industri-industri yang membayar rendah.

Bobot pekerja, masalah pokok ini banyak mendapatkan perhatian dalam bagian berikut mengenai variabel-variabel individual karena adanya dugaan bahwa tanggapan-tanggapan keperilakuan dan sikap terhadap pekerjaan sangat tergantung pada perbedaan-perbedaan individual. Dalam hal ini perhatian dipusatkan pada kumpulan hubungan antara pergantian karyawan dan ciri-ciri pekerjaan tertentu, termasuk rutinitasi atau pengulangan tugas, autonomi atau tanggung jawab pekerjaan. Gaya penyeliaan, sebuah telaah mendapati bahwa terdapat tingkat pergantian karyawan yang tertinggi dalam kelompok-kelompok 
kerja dimana mandornya atau supervisor acuh tak acuh, tanpa mempedulikan tingkat strukturnya. Selain itu didapati bahwa kurangnya pertimbangan ke penyeliaan merupakan alasan nomor dua yang paling banyak dikatakan sebagai penyebab pemberhentian karyawan.

Berdasarkan hasil penelitian sebelumnya, hipotesis yang dapat diajukan dalam penelitian ini adalah:

$\mathrm{H}_{4}$ : Kepuasan kerja berpengaruh terhadap turnover intention dengan mediasi komitmen organisasi.

Susiani (2012) melakukan penelitian dimana dalam penelitiannya menemukan bahwa kepuasan kerja berpengaruh negatif pada turnover intention melalui komitmen organisasional. Semakin tingi tingkat kepuasan kerja seorang karyawan, maka semakin tinggi pula komitmen mereka terhadap perusahaan dan dengan demikian keinginan mereka untuk keluar dari perusahaan akan semakin rendah. Indrayanti dan Riana (2016) kemudian melakukan penelitian dengan hasil bahwa kepuasan kerja berpengaruh negatif dan signifikan terhadap turnover intention melalui mediasi komitmen organisasi.

\section{METODE PENELITIAN}

Jenis penelitian ini adalah penelitian asosiatif kuantitatif dengan menggunakan survey yaitu penelitian untuk mencari hubungan antara variabel yang berlandaskan positif yang dilakukan pada sampel populasi sehingga dapat ditemukan hubungan antara variabel.

Populasi adalah wilayah generalisasi yang terdiri atas objek/subjek yang mempunyai kualitas dan karakteristik tertentu yang diterapkan oleh peneliti untuk dipelajari dan kemudian ditarik kesimpulannya (Sugiyono,2010). Populasi dalam penelitian ini adalah seluruh Karyawan pada PT. ASTRA INTERNATONAL Tbk, HONDA cabang Makassar berkedudukan di jalan Sultan Alauddin No. 57 Makassar yang berjumlah 100 orang pegawai (kayawan tetap). Didirikan pada tanggal 18 Juli 1991 dan bertugas menjadi main dealer di daerah Sulawesi Selatan, Sulawesi Barat, Sulawesi Tenggara dan Ambon, membawahi 22 (duapuluh dua) sales office dan 54 dealer di wilayah Sulawesi Selatan, Barat, Tenggara dan Ambon. Kegiatan utama perusahaan ini adalah sebagai distributor sepeda motor merk Honda, sekaligus melakukan penjualan spare parts dan service khusus sepeda motor Honda.

Sampel adalah sebagian dari jumlah dan karakteristik yang dimiliki oleh populasi tersebut. (Sugiyono, 2010). Karena terbatasnya jumlah populasi penelitian, maka Sampel yang diteliti sebagai responden sama dengan jumlah populasi (100 orang pegawai). maka disebut sampel jenuh. Jumlah sampel dalam penelitian ini sebanyak 100 responden. Jumlah tersebut dalam rangka memenuhi jumlah minimal dalam sampel. hal ini untuk dapat memenuhi akan syarat minimum data untuk diolah menggunakan analisis SPSS statistic 2.2. Model analisis data yang digunakan merupakan analisis jalur (Path Analysis). Analisis jalur menurut (Ghozali, 2013) analisis perluasan dari analisis regresi linear berganda atau penggunaan analisis regresi untuk menaksirkan hubungan kausalitas antar variabel (model casual) yang sudah ditetapkan sebelumnya sesuai 
dengan teori.Analisis jalur (path analysis) pada penelitian ini adalah kepuasan kerja terhadap turnover intention dengan komitmen organisasi. Analisis jalur ini nantinya akan membantu dalam melihat besarnya koefisien secara tidak langsung dari variabel terikat terhadap variabel bebas, dengan memperhatikan besarnya koefisien. Berdasarkan nilai tersebut nantinya akan diketahui seberapa besar pengaruh tidak langsung variabel terikat dalam mempengaruhi variabel bebas melalui variabel intervening yaitu komitmen organisasi. Diagram jalur menurut (Ghozali, 2013) diatas terdiri atas dua persamaan struktural, dimana kepuasan kerja dan turnover intention merupakan variabel eksogen dan variabel endogen. Tujuan analisis jalur ini adalah menentukan pengaruh langsung maupun tidak langsung diantara sejumlah vaiabel dan analisis jalur juga digunakan dalam menguji besarnya sumbangan (kontribusi) yang ditujukan oleh koefisien jalur dari hubungan kausal antara variabel X1 dan X2 terhadap Y1 serta dampaknya kepada Y2, analisis korelasi dan regresi yang merupakan dasar dari perhitungan koefisien jalur. Analisis jalur (Path Analysis) adalah suatu bentuk terapan dari analisis multiregresi. Dengan menggunakannya dapat dihitung besarnya pengaruh langsung dari variabel-variabel bebas terhadap suatu variabel terikat. pengaruhpengaruh itu tercermin dalam apa yang disebut sebagai koefisien jalur (part coefisients) yang sesunggunya merupakan koefisien regresi yang telah dibakukan (yakni $\beta$ ). Model persamaan dalam penelitian ini adalah:

$$
\begin{aligned}
& \mathrm{Y} 1=\beta 1 \mathrm{X} 1+\beta 2 \mathrm{X} 2 \ldots \ldots \ldots \ldots \ldots(1) \\
& \mathrm{Y} 2=\beta 1 \mathrm{X} 1+\beta 2 \mathrm{X} 2+\beta 3 \mathrm{Y} 1 \ldots \ldots \ldots \ldots(2) \\
& \text { Keterangan: } \\
& \beta=\text { Besar pengaruh antara variabel independen dan variabel dependen } \\
& \mathrm{Y}=\text { Komitmen Oganisasi }
\end{aligned}
$$

\section{HASIL DAN PEMBAHASAN}

Metode pengumpulan data adalah teknik atau cara-cara yang dapat digunakan oleh peneliti untuk mengumpulkan data (Ridwan, 2011). Dilihat dari segi cara atau teknik pengumpulan data, maka teknik pengumpulan data yang digunakan dalam penelitian ini adalah angket atau kuesioner. Kuesioner merupakan alat pengumpulan data dengan cara membuat daftar pertanyaan atau pernyataan yang kemudian disebarkan kepada responden secara langsung sehingga hasil pengisiannya akan lebih jelas dan akurat. Daftar pertanyaan atau pernyataan dibuat untuk mendapatkan tanggapan responden mengenai gambaran umum, perhatian dan pendapat responden tentang pengaruh kepuasan kerja terhadap turnover intention dengan komitmen organisasi sebagai variabel intervening.

Deskripsi responden adalah penjelasan tentang keberadaan pegawai PT. Astra International Tbk, Honda, yang diperlukan sebagai informasi untuk mengetahui identitas sebagai responden dalam penelitian ini. Responden sebagai objek penelitian yang memberikan interpretasi terhadap karakteristik responden untuk menganalisis pengaruh atas Pengaruh Kepuasan Kerja Terhadap TurnOver Intention dalam Komitmen Organisasi sebagai variabel Intervening pada PT. Astra International Tbk, Honda. 
Penelitian ini menganalisis remunerasi variable independent, kinerja sebagai variable dependen dan kepercayaan atasan sebagai variable moderasi. Kepuasan Kerja (Variabel Bebas) kepuasan kerja adalah suatu sikap umum terhadap pekerjaan seseorang sebagai perbedaan antara banyaknya ganjaran yang diterima pekerja dengan banyaknya ganjaran yang diyakini seharusnya diterima menurut Robbins (2015). Yang terdiri dari beberapa indikaktor, yaitu : Pekerjaan Yang Secara Mental Menantang merupakan tanggapan responden terhadap pekerjaan yang mereka lakukan yang dapat menggunakan keterampilan dan kemampuan mereka secara menyeluruh. Yang diukur dengan Skala Ordinal dengan menggunakan Skala Likert untuk jawaban sangat baik diberikan score 5, untuk jawaban baik diberikan score 4, untuk jawaban netral diberikan score 3, untuk nilai buruk diberikan score 2, untuk nilai sangat buruk diberikan score 1, kondisi kerja yang mendukung merupakan tanggapan responden terhadap kondisi pekerjaan yang dapat mereka lakukan. Yang diukur dengan Skala Ordinal dengan menggunakan Skala Likert untuk jawaban sangat baik diberikan score 5, untuk jawaban baik diberikan score 4, untuk jawaban netral diberikan score 3, untuk nilai buruk diberikan score 2, untuk nilai sangat buruk diberikan score 1, gaji atau upah yang pantas merupakan tanggapan responden terhadap kebijakan pemberian gaji atau upah yang didasarkan oleh hasil kerja yang mereka lakukan. Yang diukur dengan Skala Ordinal dengan menggunakan Skala Likert untuk jawaban sangat baik diberikan score 5, untuk jawaban baik diberikan score 4, untuk jawaban netral diberikan score 3, untuk nilai buruk diberikan score 2, untuk nilai sangat buruk diberikan score 1, kesesuaian kepribadian dengan pekerjaan merupakan tanggapan responden terhadap kecocokan antara kepribadian seorang karyawan dengan pekerjaan yang saat ini mereka lakukan. Yang diukur dengan Skala Ordinal dengan menggunakan Skala Likert untuk jawaban sangat baik diberikan score 5, untuk jawaban baik diberikan score 4, untuk jawaban netral diberikan score 3, untuk nilai buruk diberikan score 2, untuk nilai sangat buruk diberikan score 1, rekan sekerja yang mendukung merupakan tanggapan responden terhadap kegiatan interaksi social karyawan yang dapat mendukung pekerjaan yang mereka lakukan. Yang diukur dengan Skala Ordinal dengan menggunakan Skala Likert untuk jawaban sangat baik diberikan score 5, untuk jawaban baik diberikan score 4, untuk jawaban netral diberikan score 3, untuk nilai buruk diberikan score 2, untuk nilai sangat buruk diberikan score 1 .

TurnOver Intention (Variabel Terikat) turnover intention adalah kadar atau intensitas dari keinginan untuk keluar dari perusahaan, banyak alasan yang menyebabkan timbulnya turnover intentions ini dan diantaranya adalah keinginan untuk mendapatkan pekerjaan yang lebih baik menurut (Harnoto ,2002; dalam Sianipar \& Haryanti ,2014). Menurut Mobley (2011) Yang terdiri dari beberapa indikator, yaitu :Pikiran-pikiran untuk berhenti (thoughts of quitting) merupakan tanggapan responden terhadap ketidakpuasan kerja yang dirasakan oleh karyawan sehingga menimbulkan pemikiran untuk keluar dari pekerjaannya. Yang diukur dengan Skala Ordinal dengan menggunakan Skala Likert untuk jawaban sangat baik diberikan score 5, untuk jawaban baik diberikan score 4, untuk jawaban netral diberikan score 3, untuk nilai buruk diberikan score 2, untuk nilai sangat buruk diberikan score 1, keinginan untuk meninggalkan (intention to quit) 
merupakan tanggapan responden terhadap pemikiran karyawan untuk meninggalkan pekerjaannya saat ini karena dirasa kurang baik. Yang diukur dengan Skala Ordinal dengan menggunakan Skala Likert untuk jawaban sangat baik diberikan score 5, untuk jawaban baik diberikan score 4, untuk jawaban netral diberikan score 3, untuk nilai buruk diberikan score 2, untuk nilai sangat buruk diberikan score 1, keinginan untuk mencari pekerjaan lain (intention to search for another job) merupakan responden terhadap pikiran karyawan untuk mencari pekerjaan diperusahaan lain. Yang diukur dengan Skala Ordinal dengan menggunakan Skala Likert untuk jawaban sangat baik diberikan score 5, untuk jawaban baik diberikan score 4, untuk jawaban netral diberikan score 3, untuk nilai buruk diberikan score 2, untuk nilai sangat buruk diberikan score 1 , komitmen Organisasi (Variabel Intervening) komitmen organisasional merupakan dimensi perilaku penting yang dapat digunakan untuk menilai kecenderungan karyawan untuk bertahan sebagai anggota organisasi menurut (Mowday 2001; dalam Fitriastuti, 2013). Menurut (Meyer \& Allen 1991; dalam Kurniawan,2015) Yang terdiri dari beberapa indikaktor, yaitu :

Affective Comitment (Komitmen Efektif) merupakan responden terhadap hubungan antara organisasi dengan karyawan yang didasarkan pada komitmen afektif. Yang diukur dengan Skala Ordinal dengan menggunakan Skala Likert untuk jawaban sangat baik diberikan score 5, untuk jawaban baik diberikan score 4, untuk jawaban netral diberikan score 3, untuk nilai buruk diberikan score 2, untuk nilai sangat buruk diberikan score 1 .

Continuance commitment (komitmen berkelanjutan) merupakan tanggapan responden terhadap keinginannya untuk tetap bekerja pada perusahaan yang ditempatinya bekerja saat ini. Yang diukur dengan Skala Ordinal dengan menggunakan Skala Likert untuk jawaban sangat baik diberikan score 5, untuk jawaban baik diberikan score 4, untuk jawaban netral diberikan score 3, untuk nilai buruk diberikan score 2, untuk nilai sangat buruk diberikan score 1 .

Normative commitment ( komitmen normative) merupakan tanggapan responden terhadap keinginannya untuk tetap berada dalam perusahaannya tempat dia bekerja saat ini walaupun dalam keadaan tertekan. Yang diukur dengan Skala Ordinal dengan menggunakan Skala Likert untuk jawaban sangat baik diberikan score 5, untuk jawaban baik diberikan score 4, untuk jawaban netral diberikan score 3, untuk nilai buruk diberikan score 2, untuk nilai sangat buruk diberikan score 1 .

Responden dalam penelitian ini sebanyak 100 orang pegawai yang representatif untuk dikemukakan sebagai kelayakan responden dalam memberikan informasi mengenai identitas diri mulai dari umur dari jenis kelamin.Lebih jelasnya akan diuraikan pada Tabel 1 .

Berdasarkan jenis kelamin, responden di cirikan dengan kelompok responden berjenis kelamin laki-laki lebih banyak 51 orang atau sebesar 51.0\% dibandingkan dengan responden perempuan sebesar 49 orang atau $49.0 \%$. 
Tabel 1.

Responden Berdasarkan Jenis Kelamin

\begin{tabular}{|c|c|c|c|c|c|}
\hline & & Frequency & Percent & $\begin{array}{l}\text { Valid } \\
\text { Percent }\end{array}$ & $\begin{array}{l}\text { Cumulative } \\
\text { Percent }\end{array}$ \\
\hline \multirow[t]{3}{*}{ Valid } & $\begin{array}{l}\text { lakil-laki } \\
\text { perempuan }\end{array}$ & 51 & 51 & 51 & 51 \\
\hline & & 49 & 49 & 49 & 100 \\
\hline & Total & 100 & 100 & 100 & \\
\hline
\end{tabular}

Tabel 2.

Distribusi responden berdasarkan status pernikahan

\begin{tabular}{llllll}
\hline & & Frequency & Percent & $\begin{array}{l}\text { Valid } \\
\text { Percent }\end{array}$ & $\begin{array}{l}\text { Cumulative } \\
\text { Percent }\end{array}$ \\
\hline Valid & 1 & 55 & 55 & 55 & 55 \\
& 2 & & & & \\
& & 45 & 45 & 45 & 100 \\
& Total & 100 & 100 & 100 & \\
\hline
\end{tabular}

Sumber : Data diolah 2019

Berdasarkan status pernikahan, responden dicirikan dengan kelompok responden lebih banyak yang sudah menikah dengan jumlah 55 orang atau sebesar $55.0 \%$ dibandingkan dengan responden yang belum menikah sebanyak 45 orang atau $45.0 \%$.

Berdasarkan jumlah sampel yang telah dikemukakan sebelumnya maka jumlah sampel digunakan dalam penelitian ini sebanyak 100 orang, adapun komposisinya sebagai berikut:

Tabel 3.

Komposisi data yang dianalisis

\begin{tabular}{ll}
\hline Keterangan & Besarnya Sampel \\
\hline Jumlah kuesioner yang disebar & 100 \\
Jumlah kuesioner yang kembali & 100 \\
Jumlah kuesioner yang cacat & 0 \\
Jumlah kuesioner yang digunakan & 100 \\
\hline Sumber : Datal digh 2019
\end{tabular}

Sumber : Data diolah 2019

Skala pengukuran yang dalam penelitian ini adalah skala likert. Cara pengukuran dengan skala likert adalah dengan menghadapkan seorang responden dengan sebuah pernyataan dan kemudian diminta untuk memberikan jawaban yang kemudian jawaban tersebut diberikan skor. Data yang berhasil dikumpulkan dari kuesioner selanjutnya akan diukur dengan bobot hitung 1 (satu) sampai 5 (lima) . 
Diketahui pengaruh langsung yang diberikan kepuasan kerja $(\mathrm{X})$ terhadap turnover intention $(Z)$ sebesar 0.238 , sedangkan pengaruh tidak langsung kepuasan kerja melalui komitmen organisasi (Y) terhadap turnover intention (Z) yaitu $0.833 \times 0.605=0.503$. maka pengaruh total yang diberikan kepuasan kerja (X) terhadap komitmen organisasi (Y) adalah pengaruh langsung ditambah dengan pengaruh tidak langsung yaitu: $0.238+0.503=1.336$. Maka dapat disimpulkan nilai pengaruh langsung kepuasan kerja $(X) \quad 0.833<$ nilai pengaruh tidak langsung terhadap turnover intention $(\mathrm{Z})$ melalui komitmen organisasi $(\mathrm{Y})$ sebesar 1.336. hasil ini menunjukkan bahwa secara tidak langsung kepuasan kerja $(X)$ berpengaruh signifikan terhadap turnover intention $(Z)$ melalui Komitmen organisasi (Y). Maka dapat disimpulkan sebagai berikut : Analisis pengaruh $\mathrm{X}$ terhadap $\mathrm{Y}$ :dari analisis diatas diperoleh nilai signifikansi $\mathrm{X}$ sebesar $0,000<$ 0,005 , sehingga dapat disimpulkan bahwa secara langsung terhadap pengaruh signifikansi $\mathrm{X}$ terhadap $\mathrm{Y}$, analisis pengaruh $\mathrm{X}$ terhadap $\mathrm{Z}$ : dari analisis diatas diperoleh nilai signifikansi $X$ sebesar $0,028<0,005$, sehingga dapat disimpulkan bahwa secara langsung terhadap pengaruh signifikansi $\mathrm{X}$ terhadap $\mathrm{Z}$, analisis pengaruh $\mathrm{Y}$ terhadap $\mathrm{Z}$ : dari analisis diatas diperoleh nilai signifikansi $\mathrm{X}$ sebesar $0,000<0,005$, sehingga dapat disimpulkan bahwa secara langsung terhadap pengaruh signifikansi $\mathrm{Y}$ terhadap $\mathrm{Z}$, analisis pengaruh $\mathrm{X}$ melalui $\mathrm{Y}$ terhadap $\mathrm{Z}$ : diketahui pengaruh langsung yang diberikan $X$ terhadap $Z$ sebesar 0,238. Sedangkan pengaruh tidak langsung $\mathrm{X}$ melalui $\mathrm{Y}$ terhadap $\mathrm{Z}$ adalah perkalian nilai beta $X$ terhadap $Y$ dengan nilai beta $Y$ terhadap $Z$ yaitu :0,833 X 0,605 =0,503. Maka pengaruh total yang diberikan $X$ terhadap $Z$ adalah pengaruh langsung ditambah dengan pengaruh tidak langsung yakni : $0,238+0,503=0,741$.

Tabel 4.

Hasil Uji Multikolinearitas

\author{
Collinearity Statistics
}

\begin{tabular}{lcl} 
Model & Tolerance & VIF \\
\hline $1 \quad$ (Constant $)$ &
\end{tabular}

KEPUASAN KERJA

KOMITMEN ORGANISASI

$0.306 \quad 3.271$

0.306

3.271

a. Dependent Variable: TURNOVER

Sumber: output spss 22.0 for window 
Berdasarkan Tabel 4. di atas terlihat bahwa nilai tolerance mendekati angka 1 dan nilai variance inflation factor (VIF) di sekitar angka 1 untuk setiap variabel, yang ditunjukkan dengan nilai tolerance untuk kepuasan kerja 0.306 dan komitmen organisasi 0.306. Selain itu nilai VIF untuk kepuasan kerja 3.271 dan komitmen organisasi 3.271. Suatu model regresi dikatakan bebas dari problem multiko apabila memiliki nilai VIF kurang dari 10. Dengan demikian, dapat disimpulkan bahwa model persamaan regresi tidak terdapat problem multiko dan dapat digunakan dalam penelitian ini.

Uji Heteroskedestisitas bertujuan untuk menguji apakah dalam model regresi terjadi ketidaksamaan variance dari residual satu pengamatan kepengamatan lainnya. Jika variance dari residual satu pengamatan ke pengamatan tetap, maka disebut homoskedastisitas dan berbeda disebut heteroskedestisitas. Untuk mengetahui ada tidaknya gejala heterokedastisitas dapat dilakukan dengan menggunakan grafik heterokedastisitas antara nilai prediksi variabel dependen dengan variabel indepeden. Dari scatterplots dibawah ini terlihat titik-titik menyebar secara acak serta tersebar baik diatas maupun dibawah angka 0 dan sumbu $\mathrm{Y}$, hal ini dapat disimpulkan bahwa tidak terjadi heterokedastisitas pada model regresi, sehingga model regresi layak untuk digunakan dalam melakukan pengujian. Untuk lebih jelasnya dapat dilihat pada gambar berikut.

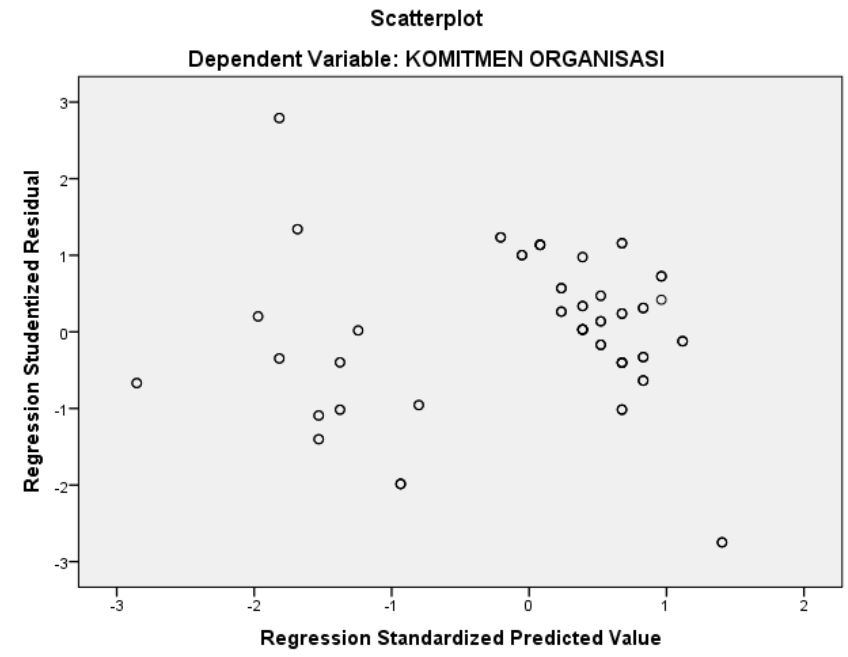

Gambar 1. Hasil Uji Heteroskedastisitas

Sumber : Output SPSS 22.0 for Windows

Berdasarkan pengujian coefficient regresi menunjukkan nilai signifikan $0,000<0,05$ dan nilai $\mathrm{T}_{\text {hitung }} 14.918>\mathrm{t}_{\text {tabel }}$ 1.983. Maka dapat disimpulkan bahwa kepuasan kerja mempunyai pengaruh positif signifikan terhadap komitmen organisas, Dengan demikian $\mathrm{H}_{\mathrm{o}}$ ditolak $\mathrm{H}_{\mathrm{a}}$ diterima .Berdasarkan hasil penelitian ini, peneliti menyimpulkan bahwa kepuasan kerja berpengaruh terhadap komitmen organisasi. 
Faktor penyebab positif dan signifikan kepuasan kerja terhadap komitmen organisasi PT. Astra International Tbk, Honda diakibatkan karena organisasi mampu membuat karyawan puas terhadap pekerjaannya sehingga tingkat kepuasan karyawan sangat tinggi.

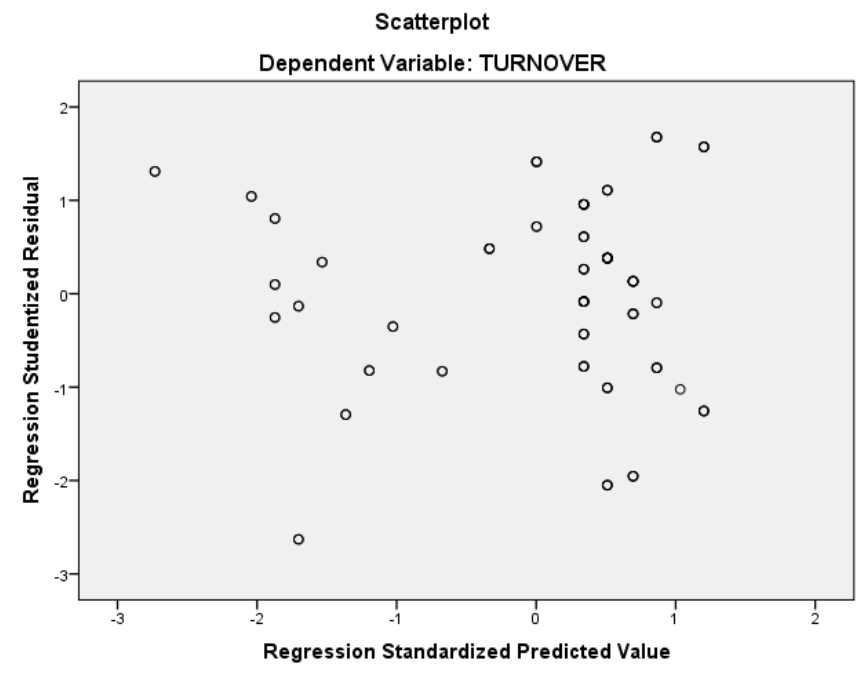

Gambar 2. Hasil Uji Heteroskedastisitas

Sumber : Output SPSS 22.0 for Windows

Tabel 5.

Hasil Uji Regresi Model 1 (Model Summary)

Std.

Adjusted Error of

\begin{tabular}{lllll} 
Model & $\mathbf{R}$ & $\begin{array}{l}\text { R } \\
\text { Square }\end{array}$ & $\begin{array}{l}\text { R } \\
\text { Square }\end{array}$ & $\begin{array}{l}\text { the } \\
\text { Estimate }\end{array}$ \\
\hline 1 & $.833^{\mathrm{a}}$ & .694 & .691 & .36163 \\
\hline
\end{tabular}

a. Predictors: (Constant), KEPUASAN KERJA

b. Dependent Variable: KOMITMEN ORGANISASI

Sumber : Data primer diolah, Tahun 2019

Tabel 6.

Hasil Uji Regresi Model II (Model Summary)

Std.

Adjusted Error of

$\mathbf{R} \quad \mathbf{R}$ the

\begin{tabular}{lllll} 
Model & R & Square & Square & Estimate \\
\hline
\end{tabular}

a. Predictors: (Constant), KOMITMEN ORGANISASI, KEPUASAN KERJA

b. Dependent Variable: TURNOVER

Sumber : Data primer diolah, Tahun 2019 
Tabel 7.

Hasil Uji Regresi Model 1 ( Cofficinents )

\begin{tabular}{|c|c|c|c|c|c|}
\hline \multirow[b]{2}{*}{ Model } & \multicolumn{2}{|c|}{$\begin{array}{l}\text { Unstandardized } \\
\text { Coefficients }\end{array}$} & $\begin{array}{l}\text { Standardized } \\
\text { Coefficients }\end{array}$ & \multirow[b]{2}{*}{$\mathbf{T}$} & \multirow[b]{2}{*}{ Sig. } \\
\hline & B & $\begin{array}{l}\text { Std. } \\
\text { Error }\end{array}$ & Beta & & \\
\hline $1 \quad$ (Constant) & -.789 & .330 & & -2.390 & .019 \\
\hline $\begin{array}{l}\text { KEPUASAN } \\
\text { KERJA }\end{array}$ & 1.196 & .080 & .833 & 14.918 & .000 \\
\hline
\end{tabular}

Sumber : data primer diolah, Tahun 2019

rumus :

$$
\begin{aligned}
\text { e1 } & =\sqrt{ }(1-\mathrm{R} \text { Square }) \\
& =\sqrt{ }(1-0,694) \\
& =\sqrt{ } 0,306
\end{aligned}
$$

Tabel 8.

Hasil Uji Regresi Model 1 ( Cofficinents )

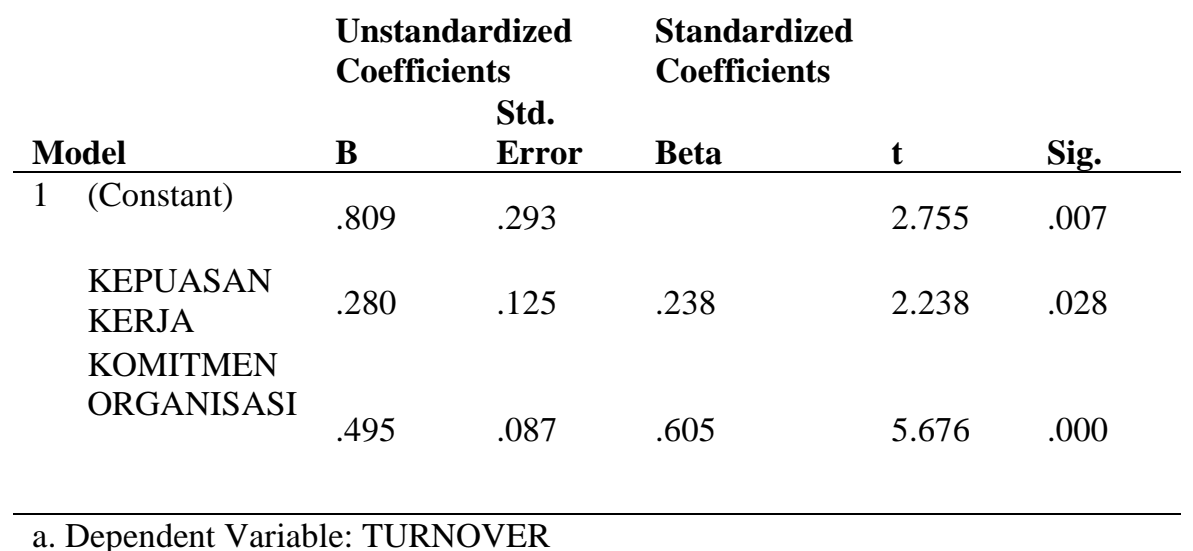

Sumber : Data primer diolah, Tahun 2019 
rumus :

$$
\begin{aligned}
& \text { e1 }=\sqrt{ }(1-\mathrm{R} \text { Square }) \\
& =\sqrt{ }(1-0,663) \\
& =\sqrt{ } 0,337 \\
& =0,580
\end{aligned}
$$

Hasil penelitian ini sejalan dengan penelitian yang dilakukan oleh Perryer $e t$ al. (2010) serta Kell \& Motowidlo (2012) yang mengemukakan bahwa kepuasan kerja berpengaruh terhadap komitmen organisasi. Berdasarkan pengujian coefficient regresi menunjukkan nilai signifikan $0,028<0,05$ dan nilai $t_{\text {tabel }} 2.238$ $>t_{\text {hitung }}$ 1.983. Maka dapat disimpulkan bahwa kepuasan kerja mempunyai pengaruh positif signifikan terhadap turnover intention. Dengan demikian $\mathrm{H}_{\mathrm{o}}$ ditolak $\mathrm{H}_{1}$ diterima. Berdasarkan hasil penelitian ini didapatkan kesimpulan bahwa kepuasan kerja berpengaruh negative signifikan terhadap turnover intention.

Faktor penyebab positif dan signifikan kepuasan kerja terhadap turnover intention PT. Astra International Tbk, Honda diakibatkan karena kepuasan kerja karyawan sangat tinggi sehingga pikiran karyawan untuk berpindah dari pekerjaannya sangat rendah sehingga mengakibatkan turnover intention tidak berpengaruh terhadap kepuasan karyawan

Hasil penelitian ini bertentangan dengan hasil penelitian yang dilakukan oleh (Andini, 2006) Pembuktian pengaruh negatif yang dilakukan peneliti berupaya untuk menjelaskan bahwa semakin tinggi kepuasan kerja, maka niat keluar karyawan dari perusahaan cenderung rendah . Berdasarkan pengujian coefficient regresi menunjukkan nilai signifikan $0,000<0,05$ dan nilai $t_{\text {hitung }} 5.676$ $>t_{\text {tabel }}$ 1.983. Maka dapat disimpulkan bahwa komitmen organisasi mempunyai pengaruh positif signifikan terhadap turnover intention. Dengan demikian $\mathrm{H}_{\mathrm{o}}$ diterima $\mathrm{H}_{\mathrm{a}}$ ditolak. Berdasarkan hasil penelitian ini didapatkan kesimpulan bahwa komitmen organisasi berpengaruh negative signifikan terhadap turnover intention.

Faktor penyebab positif dan signifikan komitmen organisasi terhadap turnover intention PT. Astra International Tbk, Honda diakibatkan karena komitmen organisasi terhadap karyawan sangat tinggi sehingga pikiran karyawan untuk berpindah dari pekerjaannya sangat rendah sehingga mengakibatkan turnover intention tidak berpengaruh terhadap komitmen organisasi.

Hasil penelitian ini bertentangan dengan hasil penelitian yang dilakukan oleh (Amriet al., 2017; Sutanto \& Gunawan, 2013) memperlihatkan turnover intention dipengaruhi secara negatif oleh komitmen organisasi. Diketahui pengaruh langsung yang diberikan kepuasan kerja (X) terhadap turnover intention (Z) sebesar 0.238, sedangkan pengaruh tidak langsung kepuasan kerja melalui komitmen organisasi $(\mathrm{Y})$ terhadap turnover intention $(\mathrm{Z})$ yaitu $0.833 \times 0.605=$ 0.503. makapengaruh total yang diberikan kepuasan kerja $(\mathrm{X})$ terhadap komitmen organisasi (Y) adalah pengaruh langsung ditambah dengan pengaruh tidak langsung yaitu: $0.238+0.503=1.336$. 
Faktanya, bahwa kondisi tersebut diakibatkan karena kepuasan kerja mampu memberikan hubungan baik langsung ataupun tidak langsung terhadap turnover intention melalui komitmen organisasi PT. Astra International Tbk, Honda

Maka dapat disimpulkan nilai pengaruh langsung kepuasan kerja (X) $0.833<$ nilai pengaruh tidak langsung terhadap turnover intention ( $\mathrm{Z})$ melalui komitmen organisasi (Y) sebesar 1.336. hasil ini menunjukkan bahwa secara tidak langsung kepuasan kerja (X) berpengaruh signifikan terhadap turnover intention (Z) melalui Komitmen organisasi (Y).

\section{SIMPULAN}

Penelitian ini bertujuan untuk menguji pengaruh kepuasan kerja terhadap turnover intention dengan komitmen organisasi sebagai variabel intervening. Responden penelitian ini berjumlah 100 orang karyawan. Berdasarkan hasil analisis dan pembahasan model hipotesis yang diajukan, maka dapat ditarik kesimpulan sebagai berikut :Berdasarkan hasil kepuasan kerja membuktikan bahwa variabel independen, yaitu komitmen organisasi berpengaruh positif dan signifikan terhadap kepuasan kerja karyawan pada PT. Astra International Tbk,Honda maka dinyatakan hipotesis pertama diterima, berdasarkan hasil kepuasan kerja membuktikan bahwa variabel independen, yaitu turnover intention berpengaruh positif dan signifikan terhadap kepuasan kerja karyawan pada PT. Astra International Tbk,Honda maka dinyatakan hipotesis kedua ditolak.

Berdasarkan hasil komitmen organisasi membuktikan bahwa variabel independen, yaitu turnover intention berpengaruh positif dan signifikan terhadap komitmen organisasi pada PT. Astra International Tbk,Honda maka dinyatakan hipotesis kedua ditolak.

Berdasarkan hasil penelitian membuktikan bahwa Pengaruh kepuasan kerja terhadap turnover intention melalui komitmen organisasi berpengaruh positif dan signifikan terhadap PT. Astra International Tbk, Honda maka dinyatakan hipotesis kedua diterima.

\section{REFERENSI}

Dewi, N. K. C. P. (2019). Pengaruh Kepuasan Kerja Terhadap Turnover Intention Yang Dimediasi Dengan Komitmen Organisasi Pada Karyawan Nusa Penida Beach Inn. Jurnal Pendidikan Ekonomi Undiksha, 9(2), 527. https://doi.org/10.23887/jjpe.v9i2.20147

Rita Andini. (2006). KEPUASAN KERJA , KOMITMEN ORGANISASIONAL( Studi Kasus Pada Rumah Sakit Roemani Muhammadiyah Semarang ). 1112.

Setiyanto, A. I., \& Hidayati, S. N. (2017). Pengaruh Kepuasan Kerja Dan Komitmen Organisasi Terhadap Turnover Intention. JURNAL AKUNTANSI, EKONOMI Dan MANAJEMEN BISNIS, 5(1), 105. https://doi.org/10.30871/jaemb.v5i1.439 
Adiguna, A. (2014). PENGARUH KEPUASAN KERJA TERHADAP TURNOVER INTENTION PADA UKM SARIMUSTIKA DI KOTA $M A L A N G$ (Doctoral dissertation, universitas of muhammadiyah malang).

Ardana, I. (2012). Gusti Gde dkk., 2012. Raja Udayana di Bali (989-1011).

Dewi, N. K. C. P. (2019). PENGARUH KEPUASAN KERJA TERHADAP TURNOVER INTENTION YANG DIMEDIASI DENGAN KOMITMEN ORGANISASI PADA KARYAWAN NUSA PENIDA BEACH INN. Jurnal Pendidikan Ekonomi Undiksha, 9(2), 527-537.

Firdaus, A. (2017). FAKTOR-FAKTOR YANG MEMPENGARUHI TURNOVER INTENTION (Studi Pada Karyawan Perusahaan Jasa Multi Finance Di Kota Jambi). Ekonomis: Journal of Economics and Business, 1(1), 1-9.

Fitriastuti, T. (2013). Pengaruh Kecerdasan Emosional, Komitmen Organisasional dan Organizational Citizenship Behavior terhadap Kinerja Karyawan. Jurnal Dinamika Manajemen, 4(2).

Ghozali, I. (2013). Aplikasi Analisis Multivariate Dengan Program IBM dan SPSS. In aplikasi analisis multivariate dengan program ibm spss 19 (p. 113).

Ghozali, S. (2013). Manajemen Sumber Daya Manusia (HumanResource).

Hardianty, I., \& Pramadewi, A. (2014). Pengaruh Karakteristik Pribadi dan Komitmen Organisasi terhadap Loyalitas Pegawai Negeri Sipil Dinas Perindustrian Perdagangan dan Pengelolaan Pasar Kabupaten Indragiri Hulu. Jurnal Online Mahasiswa Fakultas Ekonomi Universitas Riau, 1(2).

Hanafiah, M. (2014). Pengaruh Kepuasan Kerja dan Ketidakamanan Kerja (Job Insecurity) dengan Intensi Pindah Kerja (Turnover) Pada Karyawan PT. Jurnal Psikologi, 1(3), 303-312.

Hidayat, A. S. (2018). Pengaruh kepuasan kerja terhadap komitmen organisasi dan turnover intention. Jurnal Manajemen Dan Pemasaran Jasa, 11(1), 5166.

Irvianti, L. S. D., \& Verina, R. E. (2015). Analisis Pengaruh Stres Kerja, Beban Kerja dan Lingkungan Kerja Terhadap Turnover Intention Karyawan Pada PT XL AXIATA TBK Jakarta. Binus Business Review, 6(1), 117-126.

Juniari, N. K. E., Riana, I. G., \& Subudi, M. (2015). Pengaruh Motivasi Terhadap Kepuasan Kerja Dan Kinerja Pegawai Negeri Sipil (Pns) Di Sekolah Tinggi Pariwisata Nusa Dua Bali. E-Jurnal Ekonomi dan Bisnis Universitas Udayana. 
Kurniawan, A. (2015). Pengaruh komitmen organisasi terhadap Organizational citizenship behavior (ocb) Pt x bandung. Jurnal Manajemen, 15(1), 95-118

Lofgren, J. L., Whary, M. T., Ge, Z., Muthupalani, S., Taylor, N. S., Mobley, M., ...\& Wang, T. C. (2011). Lack of commensal flora in Helicobacter pyloriinfected INS-GAS mice reduces gastritis and delays intraepithelial neoplasia. Gastroenterology, 140(1), 210-220.

Mahardika, I. G. A. G. E., \& Wibawa, I. M. A. (2015). Pengaruh Kepuasan Kerja Terhadap Turnover Intention Dengan Komitmen Organisasi Sebagai Variabel Intervening Pada Pt. Autobagus Rent Car Bali. E-Jurnal Manajemen, 4(4).

Nugroho, R. A., \& Hartono, S. (2016). Pengaruh Komitmen Organisasi, Motivasi Berprestasi dan Gaya Kepemimpinan terhadap Kinerja Karyawan PT Wangsa Jatra Lestari. Jurnal Bisnis dan Ekonomi, 23(2).

Octarina, A. (2013). Pengaruh Etos Kerja Dan Disiplin Kerja Terhadap Kinerja Pegawai Pada Dinas Kebudayaan Pariwisata Pemuda Dan Olahraga Kabupaten Sarolangun. Manajemen S-1, 1(1).

Putri, F. I. (2014). Hubungan motivasi Kerja dengan Komitmen kerja karyawan di Balai Pendidikan dan pelatihan Sosial. Jurnal Bahana Manajemen Pendidikan, 2(1), 220-232.

Prawitasari, A. (2016). Faktor-Faktor Yang Mempengaruhi Turnover Intention Karyawan Pada PT. Mandiri Tunas Finance Bengkulu. Ekombis Review, $4(2)$.

Sianipar, A. R. B., \& Haryanti, K. (2014). Hubungan komitmen organisasi dan kepuasan kerja dengan intensi turnover pada karyawan bidang produksi CV. X. PSIKODIMENSIA, 13(1), 98.

Setiyanto, A. I., \& Hidayati, S. N. (2017). Pengaruh Kepuasan Kerja dan Komitmen Organisasi terhadap Turnover Intention. JURNAL AKUNTANSI, EKONOMI dan MANAJEMEN BISNIS| e-ISSN: 2548-9836, 5(1), 105-110.

Sjahruddin, H., \& Sudiro, A. A. (2013). Organizational justice, organizational commitment and trust in manager as predictor of organizational citizenship behavior. Interdiciplinary J. of contemporary Res. Bus.(IJCRB), 4(12), 133-141.

Sugiyono, P. (2010). Dr. Metode Penelitian Pendidikan: Pendekatan Kuantitatif, Kualitatif dan R\&D Cet.

Syelly, R. M. (2014). PENGARUH HUBUNGAN INTERPERSONAL DAN LINGKUNGAN KERJA TERHADAP KEPUASAN KERJA KARYAWAN 
E-Jurnal Manajemen, Vol. 9, No. 4, 2020 : 1634-1655

PADA PT. PELINDO I CABANG PEKANBARU (Doctoral dissertation, Universitas Islam Negeri Sultan Syarif Kasim Riau).

Wright, J. T., \& Embrick, D. G. (2018). The Emotional Work of Family Negotiations in Digital Play Space: Searching for Identity, Cooperation, and Enduring Conflict. American Journal of Play, 11(1), 104-131. 